\title{
CATTLE MANURE APPLICATION AFFECTS BIOAVAILABILITY OF CADMIUM IN SOIL
}

\author{
W.D.E.P.A. Withana ${ }^{1}$, A.G.K.S.Kodikara ${ }^{2}$, C.P. Attanayake ${ }^{* 1}$ \\ ${ }^{1}$ Department of Soil Science, Faculty of Agriculture, University of Peradeniya, Sri Lanka
}

${ }^{2}$ Postgraduate Institute of Agriculture, University of Peradeniya, Sri Lanka

\begin{abstract}
Cadmium (Cd) in soil could enter human body via food chain contamination. Farmers regularly apply manure to the vegetable growing fields in the up-country in Sri Lanka. Regular manure application could increase concentration of labile $\mathrm{C}$ in soil, which could maintain relatively high soluble $\mathrm{Cd}$ fraction in soil, resulting soil Cd more bioavailable. A pot experiment was conducted in a greenhouse with soils (Ultisols) collected from an urban vegetable garden in Seethaeliya, Sri Lanka to assess whether the manure application affects the phytoavailability of soil Cd to lettuce. Lettuce was grown for three consecutive crop cycles with and without cattle manure. For one manure-added treatment, dried manure was added as a bulk (i.e. one time at the beginning of the first crop at the rate of $75 \mathrm{~g}$ of manure per $5 \mathrm{~kg}$ of soil in fresh weight basis) and as a split dose for the other treatment at the rate of $25 \mathrm{~g}$ of manure per $5 \mathrm{~kg}$ of soil at the beginning of every crop. The concentration of total $\mathrm{Cd}$ was $0.72 \mathrm{mg} / \mathrm{kg}$ in soil and $0.60 \mathrm{mg} / \mathrm{kg}$ in cattle manure. Only $2 \%$ of total Cd was easily extractable in soil, whereas $21 \%$ of total $\mathrm{Cd}$ in the manure was easily extractable. Concentration of $\mathrm{Cd}$ in lettuce was significantly higher in manure-added treatments compare to the unamended soil. Manure application (both bulk and split) increased $\mathrm{Cd}$ concentration in lettuce. Incorporation of easily extractable $\mathrm{Cd}$ and increase of labile $\mathrm{C}$ via manure application may have contributed to elevate $\mathrm{Cd}$ concentrations in lettuce.
\end{abstract}

Keywords: Cadmium, Labile C, Manure, Bioavailability

\section{Introduction}

Vegetables are an important part of the human diet. Urban soils contribute to produce significant amount of vegetables all over the world. Human activities in urban areas cause soil contamination with trace elements. Urban soils could contain moderate levels of trace elements such as lead, cadmium and chromium. Research on safe methods to grow vegetables in moderately contaminated soils has gained much attention (Brown et al., 2016). Cadmium is non-essential for plants and humans, and is a potentially toxic heavy metal that is easily taken up by plants (Ding et al., 2018 ; Bolan et al., 2003). Dietary exposure for Cd through vegetable consumption has been identified as a potential risk to human health (Jolly et al ., 2013; Wang et al., 2015). However, there are limited research published on bioavailability of $\mathrm{Cd}$ in urban soils to vegetables.

Many urban vegetable growers use organic amendments such as manure, compost, and bio-solids to improve soil fertility. The same practice would be beneficial to limit soil-plant transfer of toxic trace elements. Various organic amendments have been tested to minimize soil-plant transfer of contaminants in urban soils (Ma et al., 1997: Li et al., 2006). The effectiveness of organic amendments on reducing soil-plant transfer of trace elements depends on the properties of the organic amendments (Xu et al., 2011: Sauerbeck et al., 1977). Increase of organic C content, active $\mathrm{Fe}$ and $\mathrm{Mn}$, and soluble inorganic $\mathrm{P}$ concentrations reduce bioavailability of trace elements in organic material-amended soils. In contrast, temporary increase of Dissolved Organic C (DOC) in soils followed by incorporation of organic amendments could enhance the solubility and phytoavailability of trace elements. The readily soluble fraction of metals in soil is generally considered to be phytoavailable (Menzies et al., 2007). Manure application has shown to increase the amount of DOC in soils, either by acting as a source of DOC or by enhancing the solubilization of the soil organic matter (Schindler et al., 1992). This can facilitate the transport of metal contaminants due to the formation of soluble metal - DOC complexes (Antoniadis et al ., 2002). As quoted 
by Bolan et al. (2003), metal - DOC complexes are more mobile in soil. So, DOC in soil significantly increases the availability of metals to plants (Antoniadis et al ., 2002). In addition, such complexes might prevent trace metals from being precipitated in soils. Nearly, about $60 \%$ of vegetable production in Sri Lanka is practiced in Up-country region, where farmers practice intensive methods. Many vegetable gardens are located in highly residential areas, which have about $3200 / \mathrm{km}^{2}$ of population density. The soils could be contaminated with residential activities such as waste disposal and use of paints. Continuous use of $\mathrm{P}$ and micronutrient fertilizers for more than 40 years could also cause accumulation of $\mathrm{Cd}$ in soils. The concentration of total $\mathrm{Cd}$ in the soils ranged from 0.12-3.86 $\mathrm{mg} \mathrm{kg}^{-1}$ (Thilakaranthne et al., 2017; Premarathne et al., 2011), which is low. However, our preliminary studies showed that the bioavailability of $\mathrm{Cd}$ as a fraction of total $\mathrm{Cd}$ is relatively high (i.e. $~ 80 \%$ ) in these soils (Thilakarathne et al., 2017). The acidity in soils and frequent manure application could be contributing to high bioavailability of $\mathrm{Cd}$ in soils. Farmers in this region use inorganic fertilizer mixtures in combination with cattle and poultry manure (Wijewardhana et al., 2012; Premarathna et al ., 2011). Farmers grow two to three crops per year consecutively, applying two to eight times more organic and inorganic fertilizers than the recommended amounts (Jayathilaka et al., 1989).

We hypothesize that regular manure application maintains a high labile $\mathrm{C}$ fractions in soil, throughout the cultivation period, which facilitates $\mathrm{Cd}$ uptake by plants. Since manure application is common in vegetable cultivation, it is important to test how it affects soil $\mathrm{Cd}$ availability for plants. The present study was undertaken to identify the effect of manure application and its frequency on phytoavailability of soil Cd to Lettuce.

\section{Material and Methods}

The experiment was conducted in 2018 . Soil ( $0-15 \mathrm{~cm}$ depth) was collected from Seethaeliya Agriculture farm in Nuwaraeliya district in Sri Lanka at the coordinates, 70 15' 6.30" N and 800 35'37.62" E. The soil was Red Yellow Podzolic (RYP) that belongs to Ultisols soil order with Typic Paleudults and Typic Hemitropepts (Mapa et al., 1999). The pot experiment was conducted in a plastic plant-house with lettuce plants (Lectuca sativa L.) for three consecutive growing periods. Each growing period was 54 days long. The timeline of the experiment was given in the Figure 1. The pots were filled with $5 \mathrm{~kg}$ of air dried-soils, which were passed through a $5 \mathrm{~mm}$ sieve. Dried cattle manure was purchased from a shop, where manure is being supplied to farmers. Cattle manure were also passed through a $5 \mathrm{~mm}$ strainer.

Soil samples were analyzed for Available N, P, K, Cation Exchange Capacity, Mehlich 3 extractable Cd, total Cd, soil $\mathrm{pH}$, electrical conductivity (EC), organic carbon, ammonium oxalate extractable Fe and Mn, permanganate oxidizable carbon (POXC) and soil texture. Available N content in soil was determined by using the Regular Kjeldahl method (Bremner, 1960). Available P content in the soil was determined by using Mehlich 3 extraction (Mehlich, 1984). Available K content in soil was determined by using Ammonium acetate method (Ure, 1993). Mehlich 3 extractable Cd was extracted (Mehlich, 1984) and analyzed by using Agilent 200 Series Graphite Furnace Atomic Absorption Spectrophotometer (GF- AAS). Soil sample was digested by using Aqua - regia solution to analyse total $\mathrm{Cd}$. Aqua - regia was prepared by using 3:1 $\mathrm{HCl}: \mathrm{HNO}_{3}$ acids from trace metal grade. Digestion was done by hot plate method as explained by Hseu et al. (2002) and solutions were analyzed for $\mathrm{Cd}$ by GF-AAS. Soil $\mathrm{pH}$ was determined by using a 1:10 soil: deionized water mixture and measured by using EUTECH pH 510 pH meter and EC was measured by using EUTECH CON 2799 EC meter. The Walkley-Black procedure was used to determine organic C content in soils (Nelson and Sommers, 1996). POXC was extracted according to the method explained by Culman et al. (2012) and analyzed using UV visible spectrophotometer at $550 \mathrm{~nm}$ wavelength (SHIMADZU, UV - 1601). Amorphous Fe and Mn in soil were determined by using the method, Acid Ammonium Oxalate in Darkness (Qiang et al., 1994). Texture was determined by using pipette method as explained by Day. (1965). 
Table 1:- Selected basic chemical properties of cattle manure

\begin{tabular}{ll}
\hline $\mathrm{pH}$ (manure: water $=1: 5)$ & 8.09 \\
$\begin{array}{l}\text { Electrical Conductivity } \\
\text { (manure: water }=1: 5 \text { ) }\end{array}$ & $5.57 \mathrm{mS} / \mathrm{m}$ \\
Permanganate Oxidizable C & $667 \mathrm{mg} / \mathrm{kg}$ \\
Total Cd & $0.60 \mathrm{mg} / \mathrm{kg}$ \\
Mehlich 3 extractable Cd & $0.13 \mathrm{mg} / \mathrm{kg}$ \\
Ammonium oxalate extractable & $2.5 \mathrm{mg} / \mathrm{kg}$ \\
$\mathrm{Fe}$ & \\
Ammonium oxalate extractable & $0.35 \mathrm{mg} / \mathrm{kg}$ \\
$\mathrm{Mn}$ & \\
\hline
\end{tabular}

Manure was incorporated into two of the treatments at two different time periods: In one treatment, manure was added one time at the beginning of the experiment. In the other treatment, manure was added three times at the beginning of every lettuce growing period. The amount of manure added at the end of the experiment was equal in both the treatments. Department of Agriculture (DOA) in Sri Lanka recommends adding 10T/ha cattle manure along with chemical fertilizers per growing season assuming two growing seasons per year. In this experiment, cattle manure was added excessively to the treatments to imitate the farmer's management practice in the region. A total of $75 \mathrm{~g}$ of cattle manure was added to each pot with $5 \mathrm{~kg}$ of soils in manure added treatments, considering $30 \mathrm{~T} / \mathrm{h}$ a of manure application rate by farmers assuming $1.5 \mathrm{~g} / \mathrm{cm}^{3}$ of soil bulk density. A control treatment without manure was maintained. Number of replicates were four.

All the pots were fertilized with Urea, Murate of potash (MOP) and Triple Super Phosphate (TSP) following the recommendation of DOA. After pots were filled with soil/soil-manure mixture, lettuce seeds were broadcasted. Tap water was added throughout the experiment to maintain $\sim 60 \%$ of the water holding capacity of soil based on the weight loss of the pots. Soil samples were collected soon after harvesting the crop in each growing period (Figure 1). The soil samples were air dried and sieved through a $2 \mathrm{~mm}$ sieve. Then the soil samples were labelled and stored in plastic bottles for laboratory analysis. These samples were analyzed for Mehlich 3 extractable $\mathrm{Cd}$, $\mathrm{POXC}$ and $\mathrm{pH}$.

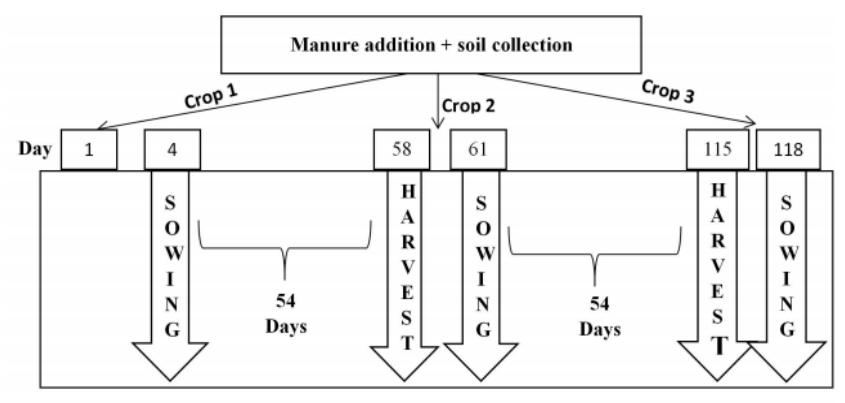

Figure 1: Timeline of the experiment

Table 2: Selected basic chemical and physical properties of soil

\begin{tabular}{ll}
\hline Total Cd & $0.72 \mathrm{mg} / \mathrm{kg}$ \\
Mehlich 3 extractable Cd & $0.017 \mathrm{mg} / \mathrm{kg}$ \\
Soil pH (Soil: water = 1:5) & 5.22 \\
Cation Exchange Capacity & $2.3 \mathrm{cmol} / / \mathrm{kg}$ \\
Available N & $129 \mathrm{mg} / \mathrm{kg}$
\end{tabular}




$\begin{array}{ll}\text { Available P } & 10 \mathrm{mg} / \mathrm{kg} \\ \text { Available K } & 151 \mathrm{mg} / \mathrm{kg} \\ \text { Organic Carbon } & 11 \% \\ \text { Permanganate Oxidizable C } & 118 \mathrm{mg} / \mathrm{kg} \\ \begin{array}{l}\text { Electrical Conductivity } \\ \text { (Soil: water = 1:5) }\end{array} & 32.41 \mu \mathrm{S} / \mathrm{m} \\ \text { Ammonium oxalate extractable Fe } & 0.20 \mathrm{mg} / \mathrm{kg} \\ \text { Ammonium oxalate extractable Mn } & 0.018 \mathrm{mg} / \mathrm{kg} \\ \text { Soil Texture } & \begin{array}{l}\text { Sand }=39 \% \\ \text { Silt= 34\% } \\ \text { clay }=27 \% \\ \text { (Clay loam) }\end{array} \\ & \end{array}$

\section{Processing of Plant Samples}

After harvesting, the lettuce leaves were thoroughly cleaned by rinsing them with distilled water, followed by 5 $\mathrm{gl}^{-1}$ Sodium lauryl sulfate $\left[\mathrm{CH}_{3}\left(\mathrm{CH}_{2}\right)_{10} \mathrm{CH}_{2} \mathrm{OSO}_{3} \mathrm{Na}\right]$ solution and then again with distilled water. This cleaning method was assumed to remove all the adhering soil dust particles from plant surfaces (Attanayake et al., 2014). Then, the plant materials were dried at $70^{\circ} \mathrm{C}$ for 4 days in a circulating oven. Plant samples were digested using a microwave digestion unit (CEM, Mars 6). In the digestion, $10 \mathrm{ml}$ of trace metal-grade $\mathrm{HNO}_{3}$ was added to $0.5 \mathrm{~g}$ of plant material. The temperature of the plant-acid mixture in the microwave digestion unit was increased to $180^{\circ} \mathrm{C}$ within 15 minutes, and the mixture was held at the same temperature for another 15 minutes.

Concentrations of Cd in soil and plant extracts were determined using GF - AAS. Quality of sample analysis were assured following USEPA method 7010 (USEPA Method 7010, 2007). The standard reference material, NIST 2586 was used. The recovery of $\mathrm{Cd}$ in the standard reference material was $87 \%$. The recovery of the spiked samples was between $90-110 \%$.

\section{Statistical Analysis}

Data were analyzed using SAS 9.1 Statistical Software as a Split Plot in a Complete Randomized Design. Main plot factor was manure treatments and the sub-plot factor was soil sampling time (or number of crop). PROC GLM procedure was used in the analysis.

\section{Results and Discussion}

The soil was acidic ( $\mathrm{pH}=5.22$, Table 2 ) as mostly observed in Tropical Ultisols. Soil $\mathrm{pH}$ gradually decreased in all the treatments, including in the control, over the three crops (Table 3). Application of urea and P fertilizers may have caused reducing soil pH (Cai et al., 2011; Schroder et al., 2011). Soil pH was relatively high in manureadded treatments due to high $\mathrm{pH}$ of the manure (i.e. $\mathrm{pH}=8.09$; Table 1). Continuous addition of manure for vegetable cultivation may have caused build-up of organic $\mathrm{C}$ in the soils used in the experiment as indicated by high organic $\mathrm{C}$ content. The POXC indicates, that the soil had a low concentration of labile $\mathrm{C}$, which was $0.1 \%$ of the total organic $\mathrm{C}$ in soil. The $\mathrm{Cd}$ concentration of soil was low (i.e. $0.72 \mathrm{mg} / \mathrm{kg}$ ), implying the soil was not excessively contaminated with Cd (United States Environmental Protection Agency, 1994; European Communities, 1986). Dilution of total Cd by organic amendments and losses due to leaching, crop uptake and erosion may have contributed to maintain low $\mathrm{Cd}$ concentrations in soils, regardless of continuous contaminations occurring due to residential and agricultural activities over 40 years. Concentration of Mehlich 3 extractable $\mathrm{Cd}$ indicated that only about $2 \%$ of the total $\mathrm{Cd}$ was extractable in soil. Total $\mathrm{Cd}$ concentration of manure was 0.60 $\mathrm{mg} / \mathrm{kg}$, which was lower than the standard of Sri Lanka Standards Institution (SLSI), (i.e. $10 \mathrm{mg} / \mathrm{kg}$; Wijesekara 
et al., 2011). However, $21 \%$ of $\mathrm{Cd}$ in the tested manure was easily extractable as indicated by the Mehlich 3 extractable $\mathrm{Cd}$ concentration. The extractability of trace elements in the organic amendments have not been included in the quality standards. The extractability of elements in manure can change as the manure decomposes (Li et al., 1994). Therefore, it is important to study the extractability of toxic elements in soil-manure mixture to assess the risk of bioavailability of the elements in amended soils.

Permanganate Oxidizable C quantifies labile soil C (Shahriari et al., 2012). It is sensitive to changes in management and environmental variations (Culman et al., 2012). Manure-added treatments had significantly higher labile $\mathrm{C}$ concentration than the control. Results indicated that frequency of manure additions had affected the labile $\mathrm{C}$ fraction in soil (Table 3). One time manure-added treatment showed gradual reduction in POXC with the time. This indicated that soil labile $\mathrm{C}$ pool was gradually reduced over the three growing seasons. In threetimes manure-added treatment, a gradual increase in POXC was observed. For this treatment, at the beginning of each crop, $25 \mathrm{~g}$ of manure, which had $667 \mathrm{mg} / \mathrm{kg}$ of POXC was incorporated. Initially, added manure was decomposed with time and gradually the decomposition rate may have decreased. As said by Li et al., (1994), when Soil Organic C (SOC) in each pool decomposes, it's C will be partially transferred to another SOC pool, partially assimilated into microbial biomass, and partially converted into $\mathrm{CO}_{2}$. Soluble $\mathrm{C}$ is produced as an intermediate product during decomposition and they are immediately consumed by microbial biomass in the soil.

According to the observed data, while organic matter subjected to decomposition, more frequent manure addition had maintained relatively high $\mathrm{Cd}$ concentration in plants. We used Mehlich 3 extraction to recover potentially bioaccessible $\mathrm{Cd}$ fraction in soil. Mehlich 3 extraction is acidic $(\mathrm{pH} 2 \pm 0.1$ ) and able to extract soluble, exchangeable, carbonate and organically bound $\mathrm{Cd}$ except for the $\mathrm{Cd}$ bound within silicate minerals (Chavez et al., 2016). Acid soluble $\mathrm{Cd}$ is a major contributor to plant available $\mathrm{Cd}$ (Chavez et al., 2016). According to the study of Chavez et al. (2016), nearly $60 \%$ of the Cd was related to acid soluble fraction and bound to organic matter. Acid soluble Cd fraction is highly correlated with Mehlich 3 extractable Cd (Chavez et al., 2016). Table 3 indicates variation of Mehlich 3 extractable $\mathrm{Cd}$ over the three growing periods in the treatments. Manure addition didn't show any significant difference in Mehlich 3 extractable $\mathrm{Cd}$ concentration in soil at $\mathrm{P}<0.05$. However, this observation does not overrule the possibility of increasing $\mathrm{Cd}$ solubility due to soluble $\mathrm{C}$ added via manure, because Mehlich 3 extractable $\mathrm{Cd}$ was determined at the end of the lettuce growing period, which was 54 days after manure addition. During this period, changes of Cd solubility was not captured by the Mehlich 3 extraction; therefore, plant available $\mathrm{Cd}$ would be a better indication for the possible solubility of $\mathrm{Cd}$ due to manure addition in this experiment.

Concentration of $\mathrm{Cd}$ in lettuce were given only for the $2^{\text {nd }}$ crop (Figure 2). In the $1^{\text {st }}$ crop, the plant dry matter contents were very little, hence; reliable data couldn't be produced. Concentrations of $\mathrm{Cd}$ in lettuce were excessive, given the low concentration of $\mathrm{Cd}$ in soils. The Codex Alimentarius Commission (CODEX), established by the Food and Agriculture Organization (FAO) and World Health Organization, develops international food standards, guidelines, and codes of practice to protect the health of the consumers and ensure fair practices in the food trade. According to CODEX, vegetables should contain less than $1.4 \mathrm{mg} / \mathrm{kg}$ of Cd dry weight basis for safe consumption, assuming $94 \%$ of plant dry matter (JECFA, 1993). Manure added treatments show more $\mathrm{Cd}$ than the CODEX standard. However, it is important to note that our unpublished data in the field studies indicates that concentrations of $\mathrm{Cd}$ in the vegetables were much lower than the CODEX standard. Soil acidity should have played a major role in high $\mathrm{Cd}$ concentrations in lettuce in this study. Soil was acidic throughout the experiment period. Initial soil pH 5.22 was reduced up to 4.31. Lettuce plant may have suffered from high acidity and resulted poor plant growth and higher $\mathrm{Cd}$ accumulation. Plants under stress tend to accumulate high concentrations of toxic trace elements (Kabata - Pendias, 2004). In addition, Cd in soil become highly bioavailable in acidic soil pH (John et al .,1972 ; Chuan et al ., 1996). Cadmium occurs principally as a free metal ion at low $\mathrm{pH}$, but availability decreases as soil $\mathrm{pH}$ is raised, because of the lower solubility of metalmineral complexes and increased adsorption by negatively charged soil colloids. 
Table 3: pH, labile C and extractable Cd in soils

\begin{tabular}{|c|c|c|c|c|c|c|c|c|c|}
\hline & \multicolumn{3}{|c|}{----------------Crop 1----------------- } & \multicolumn{3}{|c|}{ 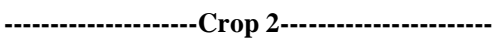 } & \multicolumn{3}{|c|}{ - } \\
\hline & $\begin{array}{l}\text { POXC } \dagger \\
(\mathrm{mg} / \mathrm{kg})\end{array}$ & Soil pH & $\begin{array}{l}\text { Extractable } \\
\text { CdII } \\
(\mathrm{mg} / \mathrm{kg})\end{array}$ & $\begin{array}{l}\text { POXC } \\
(\mathrm{mg} / \mathrm{kg})\end{array}$ & Soil pH & $\begin{array}{l}\text { Extractable } \\
\mathrm{Cd} \\
(\mathrm{mg} / \mathrm{kg})\end{array}$ & $\begin{array}{l}\text { POXC } \\
(\mathrm{mg} / \mathrm{kg})\end{array}$ & Soil pH & $\begin{array}{l}\text { Extractable } \\
\mathrm{Cd} \\
(\mathrm{mg} / \mathrm{kg})\end{array}$ \\
\hline Control & $98 \pm 5$ & $5.14 \pm 0.003$ & $0.015 \pm 0.002$ & $149 \pm 14$ & $4.64 \pm 0.04$ & $0.019 \pm 0.000$ & $87 \pm 10$ & $4.31 \pm 0.03$ & $0.016 \pm 0.000$ \\
\hline $\begin{array}{l}\text { Manure-added: } 1 \\
\text { time }\end{array}$ & $225 \pm 5$ & $5.20 \pm 0.002$ & $0.018 \pm 0.002$ & $165 \pm 6$ & $4.82 \pm 0.01$ & $0.016 \pm 0.001$ & $131 \pm 13$ & $4.44 \pm 0.03$ & $0.016 \pm 0.001$ \\
\hline $\begin{array}{l}\text { Manure-added: } 3 \\
\text { times }\end{array}$ & $158 \pm 15$ & $5.17 \pm 0.004$ & $0.022 \pm 0.003$ & $187 \pm 5$ & $4.72 \pm 0.03$ & $0.016 \pm 0.001$ & $221 \pm 14$ & $4.34 \pm 0.06$ & $0.017 \pm 0.001$ \\
\hline
\end{tabular}

$\dagger$ POXC: Permanganate Oxidizable C

II Mehlich 3 extractable Cd

Concentration of $\mathrm{Cd}$ was significantly higher in lettuce grown in manure-added soils compared to that in the unamended soil. Plants grown in manure added pots had 7 times higher $\mathrm{Cd}$ concentration than the control. Partly, the reason for high $\mathrm{Cd}$ in lettuce grown in manure-added soil could be addition of soluble $\mathrm{Cd}$ via manure: $\mathrm{As}$ explained above, $21 \%$ of total $\mathrm{Cd}$ in the manure was easily extractable (Table 1). Cadmium added with manure may have contributed to $\mathrm{Cd}$ uptake by plants. Further, the other reason for high $\mathrm{Cd}$ concentration in lettuce could be increase of labile $\mathrm{C}$ in the soil via manure and consequently increase of solubility of $\mathrm{Cd}$ by complexing with labile $\mathrm{C}$ in soils. Soil organic C is known to complex with heavy metals. Solubility behaviour of organic matter in organic- amended soils may exert a significance influence on the solubility of metals (Ashworth and Alloway, 2008). Dissolved organic C molecules contain functional groups (e.g. carboxylic - $\mathrm{COOH}$ and phenolic - $\mathrm{OH}$ ) which are capable of complexing metals (Saar and Weber, 1982). Further, as explained by Ashworth and Alloway (2008) there are essentially three, probably interrelated processes, by which the partitioning behaviour of organic matter may influence the behaviour of heavy metals. The three processes are organic matter released into the soil solution results in the co-release of heavy metals already associated with that organic matter, organic matter released into the soil solution serves to subsequently extract or mobilize heavy metals from the solid phase, and organic matter and heavy metals released independently into the soil solution subsequently become associated with one another. Clearly, the first two of these processes would lead to an increase in the concentration of heavy metals in the soil solution. In addition, all three processes would lead to an increase in the concentration of organically complexed heavy metals in the soil solution. So, these might be the reasons for elevated $\mathrm{Cd}$ concentrations in plants grown in manure-amended soils.

In acidic soil, with the presence of soluble organic matter, soil sorbs more $\mathrm{Cd}$ than it does soil alone (Lamy et al., 1993). It seems that soil $\mathrm{pH}$ in this study was favourable to maintain high $\mathrm{Cd}$ concentration in plants. 


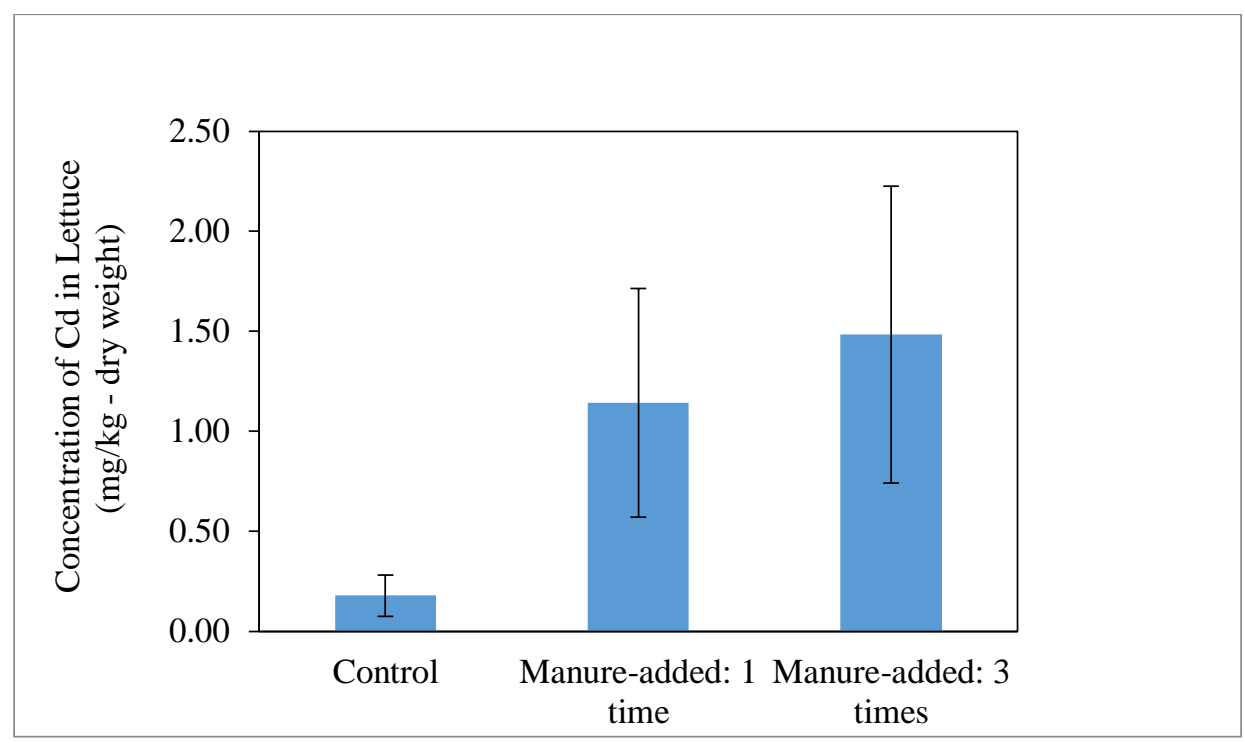

Figure 2: Concentration of Cd in lettuce shoots for crop 2

\section{Conclusion}

This pilot study revealed that cattle manure application increased the phytoavailability of $\mathrm{Cd}$ for lettuce compared to the unamended control. The reasons could be; 1 ) Manure contained $\mathrm{Cd}$ of which $21 \%$ was easily extractable, and 2) Manure increased labile $\mathrm{C}$ in the soil which could potentially increase $\mathrm{Cd}$ solubility in soils. In addition, the plant growth was affected by high acidity in soils. High acidity and poor plant growth had led lettuce to accumulate high concentrations of $\mathrm{Cd}$.

\section{Acknowledgement}

We acknowledge the funds received by the University Research Grants (Grant No: URG/2016/11/ag), University of Peradeniya, Peradeniya, Sri Lanka.

We are thankful to the Director, Agricultural Biotechnology Center, University of Peradeniya for providing greenhouse facility.

\section{References}

Antoniadis, V., \& Alloway, B. J. (2002). The role of dissolved organic carbon in the mobility of $\mathrm{Cd}, \mathrm{Ni}$ and $\mathrm{Zn}$ in sewage sludge-amended soils. Environmental Pollution, 117(3), 515-521.

Antoniadis, V., Robinson, J. S., \& Alloway, B. J. (2008). Effects of short-term pH fluctuations on cadmium, nickel, lead, and zinc availability to ryegrass in a sewage sludge-amended field. Chemosphere, 71(4), 759-764.

Ashworth, D. J., \& Alloway, B. J. (2008). Influence of dissolved organic matter on the solubility of heavy metals in sewage-sludge-amended soils. Communications in Soil Science and Plant Analysis, 39(3-4), 538-550.

Attanayake, C. P., Hettiarachchi, G. M., Harms, A., Presley, D., Martin, S., \& Pierzynski, G. M. (2014). Field evaluations on soil plant transfer of lead from an urban garden soil. Journal of Environmental Quality, 43(2), 475487.

Bolan, N. S., Adriano, D. C., Duraisamy, P., \& Mani, A. (2003). Immobilization and phytoavailability of cadmium in variable charge soils. III. Effect of biosolid compost addition. Plant and Soil, 256(1), 231-241. 
Brown, S. L., Chaney, R. L., \& Hettiarachchi, G. M. (2016). Lead in urban soils: a real or perceived concern for urban agriculture. Journal of environmental quality, 45(1), 26-36.

Bremner, J. M. (1960). Determination of nitrogen in soil by the Kjeldahl method. The Journal of Agricultural Science, 55(1), 11-33.

Cai, Z., Wang, B., Xu, M., Zhang, H., He, X., Zhang, L., \& Gao, S. (2015). Intensified soil acidification from chemical $\mathrm{N}$ fertilization and prevention by manure in an 18-year field experiment in the red soil of southern China. Journal of Soils and Sediments, 15(2), 260-270.

Chavez, E., He, Z. L., Stoffella, P. J., Mylavarapu, R. S., Li, Y. C., \& Baligar, V. C. (2016). Chemical speciation of cadmium: an approach to evaluate plant-available cadmium in Ecuadorian soils under cacao production. Chemosphere, 150, 57-62.

Chuan, M. C., Shu, G. Y., \& Liu, J. C. (1996). Solubility of heavy metals in a contaminated soil: effects of redox potential and $\mathrm{pH}$. Water, Air, and Soil Pollution, 90(3-4), 543-556.

Culman, S. W., Snapp, S. S., Freeman, M. A., Schipanski, M. E., Beniston, J., Lal, R., \& Lee, J. (2012). Permanganate oxidizable carbon reflects a processed soil fraction that is sensitive to management. Soil Science Society of America Journal, 76(2), 494-504.

Day, P. R. (1965). Particle fractionation and particle-size analysis. Methods of Soil Analysis: Part 1 Physical and Mineralogical Properties, Including Statistics of Measurement and Sampling, 9, 545-567.

Ding, C., Ma, Y., Li, X., Zhang, T., \& Wang, X. (2018). Determination and validation of soil thresholds for cadmium based on food quality standard and health risk assessment. Science of the Total Environment, 619, 700706.

Hseu, Z. Y., Chen, Z. S., Tsai, C. C., Tsui, C. C., Cheng, S. F., Liu, C. L., \& Lin, H. T. (2002). Digestion methods for total heavy metals in sediments and soils. Water, air, and soil pollution, 141(1-4), 189-205.

Jayatilleke, J., \& Bandara, J. M. R. S. (1989). Pesticide management by the hill country vegetable farmers.

Jinadasa, K. B. P. N., Milham, P. J., Hawkins, C. A., Cornish, P. S., Williams, P. A., Kaldor, C. J., \& Conroy, J. P. (1997). Survey of cadmium levels in vegetables and soils of Greater Sydney, Australia. Journal of Environmental Quality, 26(4), 924-933.

John, M. K., VanLaerhoven, C. J., \& Chuah, H. H. (1972). Factors affecting plant uptake and phytotoxicity of cadmium added to soils. Environmental Science \& Technology, 6(12), 1005-1009.

Jolly, Y. N., Islam, A., \& Akbar, S. (2013). Transfer of metals from soil to vegetables and possible health risk assessment. SpringerPlus, 2(1), 385.

Kabata-Pendias, A. (2004). Soil-plant transfer of trace elements - an environmental issue. Geoderma, 122(2-4), 143-149.

Lamy, I., Bourgeois, S., \& Bermond, A. (1993). Soil cadmium mobility as a consequence of sewage sludge disposal. Journal of Environmental Quality, 22(4), 731-737.

Li, C., Frolking, S., \& Harriss, R. (1994). Modeling carbon biogeochemistry in agricultural soils. Global biogeochemical cycles, 8(3), 237-254.

Ma, L. Q., \& Rao, G. N. (1997). Chemical fractionation of cadmium, copper, nickel, and zinc in contaminated soils. Journal of Environmental Quality, 26(1), 259-264.

Mapa, R. B., \& Somasiri, S. (1999). Soils of the wet zone of Sri Lanka: morphology, characterization and

Mehlich, A. (1984). Mehlich 3 soil test extractant: A modification of Mehlich 2 extractant. Communications in soil science and plant analysis, 15(12), 1409-1416.classification.

Menzies, N. W., Donn, M. J., \& Kopittke, P. M. (2007). Evaluation of extractants for estimation of the phytoavailable trace metals in soils. Environmental pollution, 145(1), 121-130.

Nelson, D. W., \& Sommers, L. E. (1996). Total carbon, organic carbon, and organic matter. Methods of soil analysis: Part 3 Chemical methods, 5, 961-1010. 
Premarathna, H. M. P. L., Hettiarachchi, G. M., \& Indraratne, S. P. (2005). Accumulation of cadmium in intensive vegetable growing soils in the up country.

Premarathna, H. M. P. L., Hettiarachchi, G. M., \& Indraratne, S. P. (2011). Trace metal concentration in crops and soils collected from intensively cultivated areas of Sri Lanka. Pedologist, 54(3), 230-240.

Qiang, T., Xiao-quan, S., \& Zhe-ming, N. (1994). Evaluation of a sequential extraction procedure for the fractionation of amorphous iron and manganese oxides and organic matter in soils. Science of the total Environment, 151(2), 159-165.

Saar, R. A., \& Weber, J. H. (1982). Fulvic acid: modifier of metal-ion chemistry. Environmental science \& technology, 16(9), 510A-517A.

Sauerbeck, D. R., \& Gonzalez, M. A. (1977). Field decomposition of carbon-14-labelled plant residues in various soils of the Federal Republic of Germany and Costa Rica. In Soil organic matter studies.

Schindler, D. W., Bayley, S. E., Curtis, P. J., Parker, B. R., Stainton, M. P., \& Kelly, C. A. (1992). Natural and man-caused factors affecting the abundance and cycling of dissolved organic substances in precambrian shield lakes. In dissolved organic matter in lacustrine ecosystems (pp. 1-21). Springer, Dordrecht.

Shahriari, A., Khormali, F., Kehl, M., Ayoubi, S., \& Welp, G. (2012). Effect of a long-term cultivation and crop rotations on organic carbon in loess derived soils of Golestan Province, Northern Iran. International Journal of Plant Production, 5(2), 147-152.

Thilakarathne, A., C. Attanayake, and M.M.C.B. Prasadini, R.M.E. Ekanayake. 2017. Potential bioavailability of trace elements in vegetable based cropping systems in the upcountry of Sri Lanka. In iPURSE: Peradeniya University International Research Session. University of Peradeniya, Peradeniya, Sri Lanka

United States Enviornmental Protection Agency. 1994. Land Application of Sewage Sludge: A Guide for Land Appliers on the Requirements of the Federal Standards for the Use or Disposal of Sewage Sludge, 40 CFR: EPA/831-B-93-002b Part 503. Washington, DC.

Ure, M., Thomas, R. D., \& Littlejohn, D. (1993). Ammonium acetate extracts and their analysis for the speciation of metal ions in soils and sediments. International journal of environmental analytical chemistry, 51(1-4), 65-84.

USEPA Method 3050, 1996. Acid digestion of sediments, sludges, and soils. Available from: Revised on December, 1996

USEPA Method 7010, (2007), Graphite furnace atomic absorption spectrophotometry, In: Test Methods for Evaluating Solid Waste, Physical/Chemical Methods SW-846, U.S. EPA, Washington DC.

Wang, L., Cui, X., Cheng, H., Chen, F., Wang, J., Zhao, X. ... \& Pu, X. (2015). A review of soil cadmium contamination in China including a health risk assessment. Environmental Science and Pollution Research, 22(21), 16441-16452.

Wijewardena, J. D. H., \& Amarasiri, S. L. (2012). Long-term use of potassium fertilizer for vegetable crops in the upcountry intermediate zone. Journal of the National Science Foundation of Sri Lanka, 25(1).

Xu, M., Lou, Y., Sun, X., Wang, W., Baniyamuddin, M., \& Zhao, K. (2011). Soil organic carbon active fractions as early indicators for total carbon change under straw incorporation. Biology and Fertility of Soils, 47(7), 745. 